\title{
MITMUSE OSASTAVA SID- JA SI-LÕPU VARIEERUMISE KASUTUSPÕHINE ANALÜÜS
}

\author{
ANN METSLANG
}

\section{Sissejuhatus}

$S$ id on kumulatiivne formatiiv, kus mitmus koos osastava käände tunnusega väljendub segmenteerimatult, nt pesasid (EKG: 214; EKK: 243). Siinses käsitluses nimetatakse seda formatiivi sid-lõpuks ning keskendutakse selle kahe eri variandi, sid- ja si-lõpu uurimisele. Seejuures ei nimetata osastavas tüvemitmuslikke $n e$ - ja $s$-sõnu $s i$-lõpulisteks, kuna $s$ kuulub tüvesse ja $i$ on mitmuse tunnus, st si on tüvega flektiivselt liitunud ja seda ei saaks tüvest eraldada (lootus- ja inimene-tüüp EKG: 342-343 järgi).

Lühikese ja pika mitmuse osastava varieerumist on uuritud ka varem (vt nt Trummer 2005; Kaalep 2010), vähem on aga tähelepanu pööratud sid-lõpu ja si-lõpu omavahelisele varieerumisele. Seda on tänapäeva üldkeeles täheldatud näiteks õpilaskirjandites ja internetikeeles (vt Habicht 2006: 18; Kukk 2010: 26-27; Soodla 2010: 68-70), nt vormi pesasid asemel võidakse kasutada ka pesasi, ning põhjendatud kõnekeelsusega, murdetaustaga ja loomuliku morfoloogia teooria põhimõtetega, sh topeltmarkeeringu ebavajalikkusega (ökonoomsusega) (Habicht jt 2006: 613-614; Kukk 2010: 26-27; Metslang 2012: 54-57, 2013: 515). Karin Soodla (2010: 70) on vaadanud ka sid-ja si-lõpuliste vormide astmevahelduslikkust ning silpide arvu. Külli Habichti jt järgi kasutatakse $s i$-lõppu toimetamata kirjalikes tekstides „viimasel ajal väga sageli”, näiteks tuuakse õpilaskirjandites kasutatud kõrgeid mägesi, suuri muresi jne. Tendentsi levimise põhjuseks peetakse keelekasutaja arvamust, et si-lõpp on kogu morfoloogilise info edasiandmiseks piisav ning osastava lõpp $d$ ei lisa midagi olulist, mistõttu võib loobuda topeltmarkeeringust. Samuti toetab si-lõppu murdekeelne taust (Habicht jt 2006: 613-614). Murdeti on si-lõpp levinud keskmurdes, põhiliselt selle kesk- ja kirdeosas, samuti idapoolsel Harjumaal, Järvamaal ning läänepoolsel Virumaal. Keskmurde lääne- ja kaguosas on aga pigem levinud sid-lõpulised vormid, kuigi sid-ja si-lõpp esinevad paralleelselt kogu keskmurde alal. si-lõppu kasutatakse seejuures pigem kolmanda- ja teisevältelistes tüvedes ning sid-lõppu esmavältelistes tüvedes (Valmet 1956: 25, 30-31). Rätsepa (1979: 22) järgi on si-lõpp enim levinud keskmurdes, kuid seda leidub ka saarte ja läänemurdes ning kirderannikumurdes. Nii sid-kui ka si-lõpp on ajalooliselt analoogiamoodustuslikud (Valmet 1956: 20). See tähendab, et lõpud on moodustatud ne- ja $s$-lõpuliste sõnade mitmuse osastava vormide eeskujul, nt roheline (nim) : rohelisi (mitm os); oskus (nim) : oskusi (mitm os).

Siinne analüüs on välja kasvanud 2013. aasta juulis Keeles ja Kirjanduses ilmunud artiklist „Osastava käände vormide kasutamisest eesti kirjakeeles”. Selles uuriti mitmeid pika ja lühikese osastava lõpu paralleelvariante: ainsuse vokaal- ja $t$-lõpp, mitmuse $i d$ - ja sid-lõpp, vokaal- ja sid-lõpp, vokaal- ja $i d$-lõpp ning selles artiklis käsitletav si-ja sid-lõpp. Vaadeldi ka kuue sõna 
mitmuse osastava sid- ja si-lõpu varieerumist: huvi, idee, menüü, oma, vend ja viga. Kõigi markersõnadega eelistati ülekaalukalt sid-lõppu, kuigi viie markersõnaga leidus ka si-vorme (Metslang 2013). Teemat tuleks uurida suurema hulga materjali põhjal, et leida vastus küsimusele, kas on siiski sõnu, millega eelistatakse si-lõppu, samuti tunnuseid, millest võib olla sid- ja si-lõpu varieerumine tingitud. Võimalike tunnustena tulevad nüüd vaatluse alla käändsõna muuttüüp, sõnaliik, fraasisisene analoogia ning vormi paiknemine vooru alguses või lõpus. Otsitakse seaduspärasusi, millistega neist tunnustest saab sid-ja si-lõpu varieerumist seletada. Materjalina kasutatakse internetikeelt. Arvestades internetikeele omapära - suulise ja kirjaliku keele vahepealsust -, ei tohiks toimetamata tekstid peegeldada vaid kirjakeele norminguga lubatut, vaid tegelikku keelekasutust.

Internetikeele materjal pärineb uue meedia korpusest, milles on umbes 22 miljonit tekstisõna 2000. aastate alguses kogutud toimetamata internetitekstidest, mis pärinevad jututubadest, uudisgruppidest, kommentaaridest ja foorumitest. ${ }^{1}$ Materjali kogudes keskenduti juhtudele, kus sama algvormiga leidus nii sid- kui ka si-lõpulist mitmuse osastavat, st sid-ja si-lõpp varieerusid. Morfoloogiliseks analüüsiks kasutati automaatse märgenduse programmi Estmorf $^{2}$, mille tulemusi kontrolliti kasutajaliidese päringutega ${ }^{3}$. Kuigi materjal on kogutud kvantitatiivsetele meetoditele tuginedes, on analüüsi laad kvalitatiivne.

Artikkel on jaotatud neljaks mõtteliseks osaks, millest esimese moodustavad sissejuhatus ja teoreetilise tausta - kasutuspõhise keelekirjelduse - tutvustus (1.-2. ptk). Teises osas antakse materjalist ülevaade (3. ptk) ning kolmandas esitatakse sid-ja si-lõpu varieerumise olulisemad tunnused (4. ptk), mis neljandas osas kokku võetakse (5. ptk).

\section{Kasutuspõhine keelekirjeldus}

Termini kasutuspõhine keelekirjeldus võttis esimesena kasutusele Ronald W. Langacker 1987. aastal, defineerides seda üksikasjalikumalt 1988. aastal (Barlow, Kemmer 2000: vii). Lähenemist on nimetatud nii kognitiiv-funktsionaalseks kui ka kasutuspõhiseks, et rõhutada selle olulisimat printsiipi, mille järgi keele struktuur tuleneb keelekasutusest (ja vastupidi) (Tomasello 2003: 5).

Langackeri definitsiooni järgi on kasutuspõhise lähenemise puhul kõige tähtsamad tegelik keelekasutus ja kõnelejate (keelekasutajate) teadmised sellest. Ta toob näiteks inglise keele reeglipäraselt moodustatud mitmusevormide loetelu, mida pole tegelikult vaja - piisab mitmuse moodustamise reeglist. See on aga valearusaam reeglist/loetelust (ingl rule/list fallacy). Tegelikult peaks grammatika sisaldama nii reegleid kui ka loetelusid. Viimased ei ole küll ökonoomsed, aga kui mõnd loetelu liiget kasutatakse sagedasti ja sellest saab keeleüksus (unit), ei saa üksust taandada üldistele reeglitele. Keeleüksusteks nimetatakse kinnistunud kognitiivseid struktuure, mille kõneleja on õppinud nii selgeks, et võib neid kasutada automaatselt, märkamata nende üksikuid osi või ülesehitust (Langacker 1987: 492, 494, 1988: 129-130, 2000: 2).

\footnotetext{
${ }^{1}$ http://www.cl.ut.ee/korpused/segakorpus/uusmeedia (13. X 2015).

${ }^{2}$ www.filosoft.ee (13. X 2015).

${ }^{3} \mathrm{http} / / /$ www.cl.ut.ee/korpused/kasutajaliides/ (13. X 2015).
} 
Seega on kasutuspõhisuse järgi keele struktuur ja kasutusjuhud tihedalt seotud (Barlow, Kemmer 2000: viii). Langackeri järgi on kasutusjuht (usage event) sümbolitest koosnev väljendus, mida kõneleja kasutab kindlatel asjaoludel ning kindla eesmärgiga. Kasutusjuht sõltub kontekstist. Kui tegu on kõnega, siis on kasutusjuhuks ka väljendi väljaütlemine (Langacker 1987: 494).

Tegelikku keelekasutust uurides ei saa alahinnata kasutusandmestiku tähtsust. Kui keelesüsteem on kasutusega tihedalt seotud, peavad teooria ja analüüs põhinema tegeliku keelekasutuse vaatlusandmestikul. Sellest johtub sageduse olulisus, kuna keelesüsteem põhineb kogemusel. Sagedus ühtaegu nii loob süsteemi kui ka on selle tulemus. Mida suurem on sagedus, seda suurem on kinnistumine (Barlow, Kemmer 2000: x, xv; Langacker 1987: 59).

Rõhutatud on ka kasutuse, sünkroonilise varieerumise ja diakroonilise muutuse tihedat seost. Andmestikust ilmneb mitmeid varieerumisi vormilistest sotsiaalseteni. Üks variant võib olla kinnistunud eri põhjustel. Need põhjused võivad olla nii süsteemisisesed kui ka kontekstist või situatsioonist tulenevad (Barlow, Kemmer 2000: xviii).

Kasutuspõhine lähenemine on lai teooria, mis hõlmab paljusid kognitiivse grammatika mudeleid. Eesti uurijatest on kasutuspõhist lähenemist selgitanud näiteks Pille Penjam (2008), keskendudes oma doktoritöö teooriaosas kitsamalt ühele kasutuspõhise lähenemise teooriale, konstruktsioonigrammatikale, ja Heete Sahkai (2011), tutvustades radikaalset konstruktsioonigrammatikat. Kasutuspõhisele keelekäsitlusele tugineb ka Pille Esloni $(2013,2014)$ eesti vahekeele korpusega seonduv uurimistöö.

\section{Materjal}

Uue meedia korpuse failidest otsiti kõiki mitmuse osastavaks märgendatud sõnavorme, mis esinesid nii sid- kui ka si-lõpulisena. Tekstitöötlusel ${ }^{4}$ saadud info järgi tehti otsingud uue meedia korpuse kasutajaliidesega. Kõik sõnavormid loeti ükshaaval üle: näiteks kui mingit kommentaari oli korpuses mitu korda ühesugusena, läks see arvesse ainult üks kord. Analüüsitavad sõnad käituvad morfoloogiliselt erinevalt. On sõnu, kus sid on grammatikakirjelduse järgi ainuvõimalik mitmuse osastava lõpp: EKG järgi koi-, auto- ja ematüüpi sõnad (nt koisid, autosid, emasid). Teise grupi moodustavad sõnad, kus sid-lõpp on üks paralleelvõimalus: idee-, siil-, seminar- ja õnnelik-tüüpi sõnad (nt ideid $\sim$ ideesid, siile $\sim$ siilisid, seminare $\sim$ seminarisid, õnnelikke $\sim$ õnnelikkusid). Kolmandasse gruppi kuuluvad sõnad, kus $s$ ei kuulu morfoloogilise lõpu koosseisu, vaid tüve juurde: lootus- ja inimene-tüüpi sõnad (nt paralleelvõimalusega lootusi lootuseid ja ainuvõimalik inimesi). Viimase grupi sõnu siinses artiklis ei vaadelda. Seega jäetakse andmestikust välja lootus- ja inimene-tüüpi sõnad ning materjali hulka jäävad esimesest grupist koi-, auto- ja ema-tüüpi sõnad, teisest grupist ainult siil-tüüpi sõnad, kuna materjali hulgas ei leidunud idee-, seminar- ja õnnelik-tüüpi varieeruva sid- ja si-lõpuga sõnu. Kaasa on arvatud veel kanal-tüüpi ning passiivsesse morfoloogiasse kuuluvad sõnad. Kõik nende tüüpide sõnad saavad kirjakeele normingu järgi olla mit-

${ }^{4}$ Aitäh Maret Kaskale ja Uku Raudverele abi eest materjali kogumisel ja tekstitöötlusel. 
muse osastavas sid-lõpulised, v.a kanal-tüüp (nt kanaleid), kuhu kuulus vaid üks andmestikus esinenud sõna: paidekas.

Kokku kuulub materjali 205 varieeruva sid- ja si-lõpuga sõna, sealhulgas kõik sõnad, mille mõlemat vormi leidub vaid üks kord.

Järgnevas otsitakse vastust küsimustele, kas muuttüüp, sõnaliik, fraasisisene analoogia ning vormi paiknemine vooru alguses või lõpus mõjutavad sõna sid-ja si-lõpulise mitmuse osastava varieerumist.

\section{4. sid- ja si-lõpu varieerumist mõjutavad tunnused}

\subsection{Muuttüüp}

Varieeruva sid- ja si-lõpuga oli enim auto-tüüpi sõnu (89), seejärel ema-tüüpi (56), passiivsesse morfoloogiasse kuuluvaid (54), siil-(4), kanal- (1) ja koi-tüüpi (1) sõnu. Joonis 1 illustreerib varieeruvate sõnade muuttüüpidesse jaotumist.

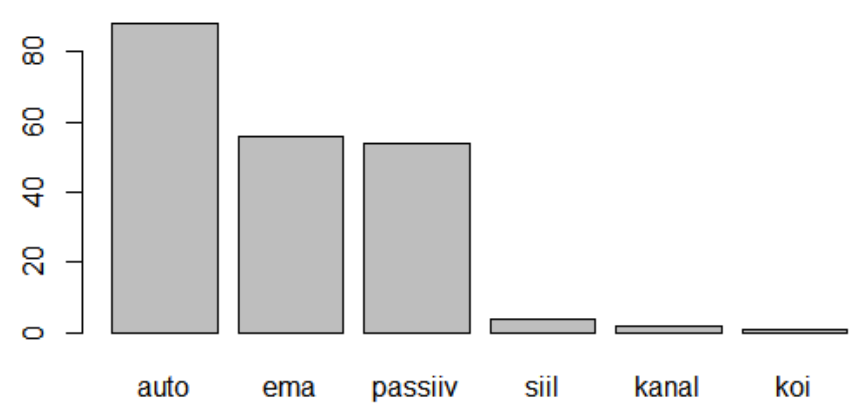

J o o n is 1. Varieeruva sid- ja si-lõpuga sõnade jaotumine muuttüübiti (passiiv = passiivsesse morfoloogiasse kuuluvad sõnad).

Jooniselt 1 nähtub, et rohkem varieerub sid- ja si-lõpp tüüpides, kus EKG järgi on sid-lõpp mitmuse osastava ainuvõimalik variant, nt autosid ja emasid. sid-lõpp on ainuvõimalik ka koi-tüübis. auto-tüübis leidus kümme sõna, kus kirjakeele normingust hälbiv si-lõpp oli levinum kui sid-lõpp: imagesi, kallasi, mersusi, muuvisi, naiskasi, nokusi, pubesi, sopranosi, spoilasi ja sudokusi. Tuleb rõhutada, et selliste vormide kasutuskordi oli väga vähe: $s i$-lõpulist vormi ainult 2-4 korda ja sid-lõpulist 1-2 korda. Nii väheste esinemiskordade põhjal ei saa üldistada, et si-lõpp oleks selgelt eelistatum.

ema-tüübis on kolm sõna, millel osutus eelistatumaks kirjakeele normingust hälbiv si-lõpp, mitte normingule vastav sid-lõpp: vormid musisi, semusi ja vibusi.

Kolmandana oli varieerumist rohkem passiivses morfoloogias, kus leidus üks sõna, millega eelistati kirjakeele normingust hälbivat si-lõppu: vorm soovilugusi. Omapärase morfoloogiaga oli pronoomen mõni, millest mitmuse osastavas kasutati ka vorme mõndasid ja mõndasi (pro mõnesid, mõnd ja 
mõnda). Seejuures on märkimist väärt, et praegused passiivse morfoloogia sõnade loendid on lõplikud ja esindavad kirjakeelt, mitte argikeelt. Argikeele all mõeldakse siin kirjakeelega võrreldes vabamat, normilõdvemat keelekuju vähenõudlikuma igapäevase suhtluse jaoks (EKK: 627). Passiivsesse morfoloogiasse kuuluvad näiteks paljud materjali astmevahelduslikud sõnad: kolm, lugu, neli, nägu, tegu jne. Kuna passiivsest morfoloogiast oli eelistatult si-lõpuline ainult üks sõna (soovilugusi), võib oletada, et passiivse morfoloogia ehk kirjakeele sõnad on eelistatult sid-lõpulised. Seega si-lõpulistena eelistatakse rohkem argikeelseid sõnu (vt auto-tüübi eelistatult si-lõpuliste sõnade loendit).

Järgmises, siil-tüübis, oli varieeruvaid sõnu vaid neli, kuid nende seas oli siiski üks, mis oli mitmuse osastavas eelistatult kirjakeele normingust hälbiv: norm : normisi (pro normisid, norme).

Materjalist võiks ainult paidekas olla kanal-tüübis: normingule vastab mitmuse osastav paidekaid. Huvitaval kombel oli aga sellest sõnast kasutatud mitmuse osastava vorme paidekasi ja paidekasid, kumbagi esines üks kord. Mõlemad tekstid pärinevad jututubadest ja on kirjutatud erineva kasutajanime alt. Näitesse 1 ja 2 on jäetud ette ja järele kontekstilaused, et vormi ümbrus selgemalt esile tuua.

(1) EVE-LIIS: ohh ikka alles

katz: mis nüüd viga

Ol4F: plju siin praegu paidekasi on?

katz: ikka alles jah

(2) kribu: mis teete?

Ashley: ma olen ju sinusse ikkagi=P@ Bicutys irw

PIKU: siin paidekasid on we

Bicutys: ähääääääääää

Ka koi-tüübist oli materjalis ainult üks sõna: täi, kaks korda kasutati vormi täisi ja kaks korda täisid.

Muuttüüp on tunnus, mis annab infot sõna aktiivsesse või passiivsesse morfoloogiasse kuulumise, astmevahelduslikkuse ja algvormi välte kohta. Siinse materjali põhjal selgub, et aktiivsesse morfoloogiasse kuuluvad sõnad varieeruvad passiivsesse morfoloogiasse kuuluvatest sõnadest rohkem. Selline tulemus on mõneti ootuspärane, kuna aktiivsesse morfoloogiasse kuulubki rohkem sõnu kui passiivsesse. Kui otstarbekas ja põhjendatud on aga aktiivsesse ja passiivsesse morfoloogiasse jaotamine üldse, pole siinse artikli teema (vt nt Ehala 1997). Esinenud muuttüüpidest on astmevahelduslik ainult siiltüüp, seega saab väita, et siinse materjali järgi on astmevahelduseta sõnadel mitmuse osastava sid- ja si-lõpu varieerumist rohkem kui astmevaheldusega sõnadel. Võrdluseks: Soodla (2010: 68-70) ei leidnud uuritud seitsme markersõna näitel, et astmevahelduslikkus si- või sid-lõpu valikut mõjutaks. Kõigist astmevahelduslikest sõnadest (siil-tüübist ja passiivsest morfoloogiast kokku 34) varieeruvad rohkem laadivahelduslikud (23), mitte vältevahelduslikud (11). Materjali põhjal varieeruvad enim teisevältelise algvormiga sõnad (autotüüpi), seejärel esmavältelise algvormiga (ema-ja kanal-tüüpi) ja vähim kolmandavältelise algvormiga sõnad (siil-ja koi-tüüpi).

Enim varieeruvate sõnade loetelu vaadates selgub, et paljud neist ei kuulu normitud kirjakeelde. Argikeelsed sõnad võivad enam varieeruda, kuna 
need ei ole normitud kirjakeeles nii levinud ning seetõttu ei ole ka kirjakeele morfoloogiareeglite rakendamine kinnistunud ja iseenesestmõistetav. Nende vormide puhul mängib rolli just kasutus. Kuigi eesti normitud kirjakeeles on mitmuse osastava moodustamise reeglid, mille järgi kumulatiivne tunnus peaks olema sid, selgub materjalist, et mõnd sõna kasutatakse eelistatult silõpulisena. Sellisel juhul võib oletada, et $s i$-lõpulised vormid on muutumas keeleüksusteks, kuna need ei lähtu üldistest mitmuse osastava moodustamise reeglitest. Võimalik, et keelekasutaja on mõne vormi üksusena omandanud ja kasutab seda automaatselt, mõtlemata selle morfoloogilisele koostisele. Hea näide on mõndasi, mis kirjakeele normingu järgi peaks olema kasutatud mõn$d a$, mõnd või mõnesid, aga mitmuse osastavas saab see osastava topeltmarkeeringu: kasutatakse nii ainsuse osastava lõppu $d a$ kui ka mitmuse osastava kumulatiivset tunnust $s i-m \tilde{n}$ ndasi. Ei saa aga öelda, et tegu oleks juba valmis keeleüksustega, kuna sel juhul peaks olema $s i$-lõpulisi vorme oluliselt rohkem kui sid-lõpulisi.

Kasutuspõhisuse kasuks räägib ka murdetaust, mille järgi võib arvata, et $s i$-lõpp pole kunagi päris taandunud olnudki, vaid on olnud sid-lõpu kõrval alati paralleelselt kasutusel. Mitmuse osastava moodustamist õpetatakse koolis, seetõttu eelistab ortograafiareegleid järgida tahtev keelekasutaja sid-lõppu $s i$-lõpule. Paljudes kirjalikes tekstides on si-lõppe sid-lõppudeks parandanud keeletoimetajad. Siiski kasutatakse $s i$-lõpulist mitmuse osastavat suulises kõnes ja toimetamata kirjalikes tekstides.

\subsection{Sõnaliik}

Ühe varieerumist mõjutava tunnusena vaadati ka sõnaliiki. Siinse materjali sõnadest varieeruvad enim substantiivid: vaatlusalusest 205 sõnast on 186 substantiivid. Sellest ei saa siiski ulatuslikumat järeldust teha, kuna pole teada, missugune on analüüsitud tekstides sõnaliikide omavaheline suhe. Varieeruva sid- ja si-lõpuga adjektiive leidus materjalis kaheksa, vähem oli numeraale, pronoomeneid ja üksikuid substantiive-adjektiive (nt kalla, muska, musi ja püha, mis võivad olenevalt kontekstist käituda nii substantiivide kui ka adjektiividena) ning substantiiv või pronoomen osa (nt osasi(d) naisi).

Materjalis on varieeruvaid adjektiive vähem kui substantiive. Nii võiks oletada, et laiendist ja põhisõnast koosnevates fraasides, kus laiend (nt kena) on adjektiiv ja põhisõna substantiiv (nt auto), varieerub eelkõige substantiiv, ning adjektiivne laiend varieerumisele nii hästi ei allu (st pigem kenasid autosi, mitte kenasi autosid). Seda saab täpsemalt jälgida järgmises, fraasisisest analoogiat käsitlevas alapeatükis.

\subsection{Analoogiamoodustus}

Üks sid- või si-lõpu valiku põhjus võib olla fraasisisene analoogia. Kui fraas koosneb laiendist ja põhisõnast, on võimalik, et tüvemitmuslik laiend mõjutab põhisõna lõpuvalikut või tüvemitmuslik põhisõna mõjutab laiendi lõpuvalikut. Näiteks fraasid uued autod või kenad naised, kus esimese laiend peaks kirjakeele normingu järgi olema osastavas tüvemitmuslik ning põhisõna sid-lõpuline: uusi autosid. Teise fraasi laiend peaks olema sid-lõpuline, põhisõna aga tüvemitmuslik: kenasid naisi. Mõnel juhul kasutatakse aga sid-lõpulise osastavavormi asemel si-lõpulist: uusi autosi või kenasi naisi. 
Järgnevates tabelites on toodud uue meedia korpuse failidest leitud ja kasutajaliidese päringutega saadud fraasid, kus laiend või põhisõna hälbib mitmuse osastavas kirjakeele normingust. Nende sagedust võrreldakse korpusest leitud kirjakeele normingule vastavate fraaside sagedusega.

\subsubsection{Fraas $-s i+*$-si ${ }^{5}$ (nt uusi osasi)}

Tabeli 1 esimeses veerus on fraasid, kus laiend on $n e$ - või $s$-lõpulise sõna tüvemitmuslik vorm: mitmuse osastava $s$ kuulub tüvesse ja mitmuse tunnus on $i$. Seega fraasi laiend on tüvemitmuses ja põhisõna on moodustatud esimese analoogial $s i$-lõpulisena. Sõnaliigiliselt oli kõigi fraaside laiend adjektiiv, v.a adjektiivne pronoomen teine, ja põhisõna substantiiv. Tabeli 1 kolmandas veerus on samade fraaside kirjakeele normingule vastav kuju. Kuna kasutuskordi on vähe, ei ole suhtarve toodud.

Tabel 1.

-si ja *-si fraasid uue meedia korpuses

\begin{tabular}{|l|c|l|c|}
\hline $\begin{array}{l}\text { Analoogiamoodustuslik } \\
\text { fraas }\end{array}$ & Sagedus & $\begin{array}{l}\text { Kirjakeele normingule vastav } \\
\text { fraas }\end{array}$ & Sagedus \\
\hline järjestikusi tekstiridasi & 1 & järjestikusi tekstiridasid & 0 \\
\hline lillelisi unenägusi & 2 & lillelisi unenägusid & 0 \\
\hline sisemisi joudusi & 1 & sisemisi joudusid & 0 \\
\hline teisi progesi & 1 & teisi progesid & 1 \\
\hline uusi autosi & 2 & uusi autosid & 3 \\
\hline uusi osasi & 1 & uusi osasid & 2 \\
\hline uusi teemasi & 1 & uusi teemasid & 5 \\
\hline värvilisi unenägusi & 3 & värvilisi unenägusid & 6 \\
\hline Kokku & 12 & & 17 \\
\hline
\end{tabular}

Kaheksast uuritud fraasist neljas on kasutatud sagedamini kirjakeele normingule vastavaid vorme (uusi autosid, uusi osasid, uusi teemasid, värvilisi unenägusid). Ühega on nii analoogiamoodustust kui ka kirjakeele normingule vastavat fraasi kasutatud mõlemat üks kord (teisi progesi(d)) ning kolmes on analoogiamoodustust kasutatud sagedamini kui kirjakeele normingule vastavaid vorme (järjestikusi tekstiridasi, lillelisi unenägusi, sisemisi joudusi, viimase kirjakeelsetest variantidest otsiti nii sisemisi joudusid kui ka sisemisi jõudusid, aga kummagagi vastet ei leitud).

${ }^{5}$ Fraaside kirjeldustes on kirjakeele normingust hälbimine märgitud tärniga. 


\subsubsection{Fraas *-si ja -si (nt kenasi naisi)}

Tabeli 2 esimeses veerus on sagedamad fraasid, mille laiend on kirjakeele normingust hälbiv si-lõpuline mitmuse osastava vorm. Põhisõna on $n e$ - või $s$-lõpuline sõna, mille mitmuse osastava $s$ kuulub tüvesse ja mitmuse tunnus on $i$. Tabeli 2 kolmandas veerus on sama fraasi kirjakeele normingule vastav kuju.

Sõnaliigiliselt leiti uue meedia korpuse failide põhjal üks adjektiivist ja substantiivist koosnev fraas (kenasi naisi), ülejäänud fraasid moodustasid pronoomen palju ning pronoomen teine või palju ning substantiivid inimene ja võimalus.

Tabel 2.

\section{*-si ja -si fraasid uue meedia korpuses}

\begin{tabular}{|l|c|l|c|}
\hline $\begin{array}{l}\text { Analoogiamoodustuslik } \\
\text { fraas }\end{array}$ & Sagedus & $\begin{array}{l}\text { Kirjakeele normingule } \\
\text { vastav fraas }\end{array}$ & Sagedus \\
\hline kenasi naisi & 4 & kenasid naisi & 7 \\
\hline paljusi inimesi & 1 & paljusid inimesi & 12 \\
\hline paljusi teisi & 2 & paljusid teisi & 10 \\
\hline paljusi võimalusi & 1 & paljusid võimalusi & 1 \\
\hline Kokku & 8 & & 30 \\
\hline
\end{tabular}

Kui eelmistes jaotistes leiti, et adjektiivid on pigem sid-lõpulised, on ka siin adjektiiv eelistatult sid-lõpuline ja analoogiamoodustusele pigem ei allu. See-eest allub analoogiamoodustusele pronoomen palju, millega leidus korpuses kolm fraasi (paljusi(d) inimesi, paljusi(d) teisi, paljusi(d) võimalusi) ning ühega neist oli analoogiamoodustuslikke ja kirjakeele normingule vastavaid fraase sama palju - mõlemat üks (paljusi(d) võimalusi).

Leidus ka selliseid fraase, mille mitmuse osastavas hälbivad kirjakeele normingust nii laiend kui ka põhisõna. Kaks korda kasutati fraasi paljusi peresi, selle kirjakeele normingule vastavat kasutusjuhtu paljusid peresid ei leitud ühtegi. Sel juhul pole aga tegu analoogiamoodustusega, kuna mõlemad on ühtmoodi si-lõpulised.

Andmete põhjal uuriti, kas pigem mõjutab laiend põhisõna või vastupidi. Fraase, kus põhisõna oli mõjutatud laiendist (tabel 1), oli 12, fraase, kus laiendit mõjutas põhisõna, oli 8 (tabel 2). Seega oli ühe kolmandiku võrra rohkem fraase, kus varieerub pigem põhisõna. See kinnitab ka sõnaliigi all oletatut, et varieerub eelkõige substantiiv ning laiend varieerumisele nii hästi ei allu. Kaisa Kasesalu (2012: 38) jõudis oma bakalaureusetöös vastupidisele tulemusele: laiendi vorm ei mõjuta põhisõna nii palju kui põhisõna vorm laiendit. Samas tuleb arvestada, et Kasesalu materjal oli kogutud küsitlusega ja uuriti lühikese ning pika mitmuse osastava analoogiat, mitte sid-ja si-lõpulise mitmuse osastava varieerumist.

Kokkuvõtteks võib oletada, et fraasisisesel analoogial pole mitmuse osastava si- või sid-lõpu valikul määrav roll, kuna analoogia põhjal loodud fraase on vähe. Samas on juba need vähesed näited tõestuseks, et analoogia mõju on olemas. 


\subsection{Paiknemine vooru alguses või lõpus}

Selles peatükis tahetakse välja selgitada, kas ka tekstilised vormitunnused võivad varieerumist mõjutada. Võib arvata, et suulises kõnes mõjutavad varieerumist prosoodilised tunnused - lauserõhk. Kas aga prosoodilised tunnused ka spontaanse teksti kirjalikus vormis väljenduda saavad? Nii oletati, et vooru alguses või lõpus paiknemine võiks sid- või $s i$-lõpu valikut mõjutada. Voor on siin pigem tehniline mõiste: rida või tekstilõik, mis kuvatakse päringu ühes reas, näiteks üks rida teksti jututoas (mis võib sisaldada mitut lauset), üks kommentaar vms. Vooru lõpuks loeti ka kõik juhud, mil vormile järgnes emotikon või kirjavahemärk.

Uue meedia korpuse failidest uuriti, milliseid si- ja sid-lõpulisi vorme leidub nii voorude alguses kui ka lõpus. Esile tuli viis sõna, neli substantiivi ja üks adjektiiv: auto, kena, lugu, nimi ja unenägu. Et selgitada, kas konkreetne vorm paikneb pigem vooru alguses või lõpus, arvutati kasutuskordade protsent esinemiskordadest.

Esmalt vaadeldi $s i$-lõpulisi vorme. Kuna $s i$-lõpuliste vormide kasutuskordi on enamasti vähem kui sid-lõpulisi, leidub neid veelgi vähem vooru alguses ja lõpus.

Tabel 3 .

Viis si-lõpulist vormi uue meedia korpuse voorude alguses

\begin{tabular}{|l|c|c|c|c|c|}
\hline \multirow{2}{*}{ Vorm } & \multirow{2}{*}{ Sagedus kokku } & \multicolumn{2}{|c|}{ Sagedus vooru alguses } & \multicolumn{2}{c|}{ Sagedus vooru lõpus } \\
\cline { 3 - 6 } & & Sagedus & $\mathbf{\%}$ & Sagedus & $\mathbf{\%}$ \\
\hline autosi & 74 & 3 & 4,1 & 2 & 2,7 \\
\hline kenasi & 45 & 5 & 11,1 & 1 & 2,2 \\
\hline lugusi & 87 & 2 & 2,3 & 3 & 3,4 \\
\hline nimesi & 90 & 6 & 6,7 & 1 & 1,1 \\
\hline unenägusi & 49 & 1 & 2,0 & 6 & 12,2 \\
\hline
\end{tabular}

Autosi, kenasi ja nimesi on eelistatult kasutusel vooru alguses, lugusi ja unenägusi vooru lõpus. Nii võiks üldistada, et $s i$-lõppu kasutatakse pigem vooru alguses. Ootuspäraselt on vooru alguses ka loetelu ainus adjektiiv kena, kuna tõenäoliselt kasutatakse seda substantiivi laiendina. Protsentuaalselt kasutatakse kõige enam vooru lõpus aga unenägusi, mis on ootuspärane sooviga lõppevates voorudes ilusaid unenägusi vms. Näitevorme ja nende kasutuskordi vooru alguses või lõpus on aga liiga vähe, järeldamaks, et $s i$-lõpu vooru alguses paiknemine on üldine tendents.

Tabelis 4 vaadeldakse sid-lõpu paiknemist vooru alguses või lõpus ning võrreldakse seda sageduste koguarvuga. 
Viis sid-lõpulist vormi uue meedia korpuse voorude alguses

\begin{tabular}{|l|c|c|c|c|c|}
\hline \multirow{2}{*}{ Vorm } & \multirow{2}{*}{ Sagedus kokku } & \multicolumn{2}{|c|}{ Sagedus vooru alguses } & \multicolumn{2}{c|}{ Sagedus vooru lõpus } \\
\cline { 3 - 6 } & & Sagedus & $\mathbf{\%}$ & Sagedus & \% \\
\hline autosid & 234 & 3 & 1,3 & 17 & 7,3 \\
\hline kenasid & 142 & 9 & 6,3 & 1 & 0,7 \\
\hline lugusid & 347 & 4 & 1,2 & 36 & 10,4 \\
\hline nimesid & 392 & 18 & 4,6 & 36 & 9,2 \\
\hline unenägusid & 148 & 1 & 0,7 & 21 & 14,2 \\
\hline
\end{tabular}

Vaadates algvorme, paiknevad kõik substantiivid - auto, lugu, nimi ja une$n \ddot{g} g u$ - eelistatult vooru lõpus, ainus adjektiiv - kena - aga vooru alguses. See on jällegi ootuspärane tulemus, kuna adjektiiv substantiivi laiendina ei saaks paikneda vooru lõpus. Nii selgubki, et sid-lõpulised substantiivid on kasutusel eelistatult vooru lõpus ning $s i$-lõpulised pigem vooru alguses. Seega eelistatakse vooru alguses lühemaid vorme ja vooru lõpus pikemaid.

\section{Kokkuvõte}

Artiklis vaadeldi üht eesti keele vormikasutuse - mitmuse osastava sid- ja si-lõpu - varieerumise juhtu ning vaadeldi konkreetseid tunnuseid, mis võiksid sid-ja si-lõpu valikut mõjutada. Põgusalt tutvustati kasutuspõhise uurimismetoodika tähtsamaid printsiipe, millest materjali kogudes ja analüüsides lähtuti. sid- ja si-lõpu varieerumise põhjustena kaaluti käändsõna muuttüüpi, sõnaliiki, fraasisisest analoogiat ja vooru alguses või lõpus paiknemist uue meedia korpuse materjali põhjal. Uurides internetikeelt, mitte ainult normeeritud kirjakeelt, leiti siinses töös ka sõnu, millega eelistatakse normingust hälbivat $s i$-lõppu. Varasemates uurimustes on sid-ja si-lõpu varieerumist selgitatud kõne- ja murdekeelsuse, ökonoomsustaotluse jm-ga.

Neljast morfoloogilist varieerumist tingida võivast tunnusest esimene näitas mitmuse osastava sid- ja si-lõpu varieerumist enam muuttüüpides, kus sid-lõpp oli kirjakeelenormingu järgi mitmuse osastavas ainuvõimalik variant: auto- ja ema-tüüpi sõnad. Sõnaliik oli varieeruvatel sõnadel enamasti substantiiv, harva oli tegu adjektiividega. Fraasisisesel analoogial pole mitmuse osastava sid- või si-lõpu valikul määrav roll, kuigi vähesed näited osutasid, et pigem võib laiend mõjutada põhisõna lõpuvalikut, mitte vastupidi. Vooru alguses ja lõpus paiknemist uurides selgus, et sid-lõpulised substantiivid, erinevalt adjektiividest, on kasutusel eelistatult vooru lõpus ning si-lõpulised pigem vooru alguses. Välja toodi sõnad, mille puhul eelistati kirjakeele normingust hälbivat mitmuse osastava vormi. Siinjuures oletati, et üksiksõnu võidakse käänata mõne teise paradigma eeskujul, st tegu on tüübianaloogiaga, mis olenevalt sõna silbistruktuurist võib varieerumisel oluline olla. Kuna enamasti 
oli tegu argikeelsete sõnadega, mitte normikirjakeelde kuuluvate sõnadega, saaks n-ö hälbiva vormivaliku eelistamist põhjendada kasutuspõhisusega keelekasutajate harjumusega ja ehk ka süveneva kasutustavaga.

Käsitluses keskenduti ühe allkeele - internetikeele - mitmuse osastava sid- ja si-lõpu varieerumise juhtudele. Ühe keelenähtuse varieerumise juhud peaksid tooma selgust eesti keele morfoloogilisse varieerumisse üldisemalt. Püüti vastata küsimusele, missugused tunnused ühe nähtuse morfoloogilisi valikuid mõjutavad. Siinsest käsitlusest ilmneb, et sid-ja si-lõpu varieerumist saab seletada peaaegu kõigi nelja tunnusega või nende koosmõjuga.

Artikli valmimist on toetanud SA Eesti Rahvuskultuuri Fondi Wiedemanni fond.

\section{Kirjandus}

B a r low, Michael, Ke m m e r, Suzanne 2000. Introduction: A usage-based conception of language. - Usage-based Models of Language. Toim M. Barlow, S. Kemmer. Stanford-California: CSLI Publications, lk vii-xxviii.

Ehala, Martin 1997. Eesti morfoloogia olemus. - Keel ja Kirjandus, nr 6, lk 370383.

EKG = Mati Erelt, Reet Kasik, Helle Metslang, Henno Rajandi, Kristiina Ross, Henn Saari, Kaja Tael, Silvi Vare 1995. Eesti keele grammatika I. Tallinn: Eesti Teaduste Akadeemia Eesti Keele Instituut.

EKK = Mati Erelt, Tiiu Erelt, Kristiina Ross 2007. Eesti keele käsiraamat. 3., täiendatud trükk. Tallinn: Eesti Keele Sihtasutus.

Es lon, Pille 2013. Kahe keelekasutusvariandi võrdlus: morfoloogilised klassid ja klastrid. - Lähivertailuja. Lähivõrdlusi, nr 23, lk 13-38.

Es lo n, Pille 2014. Eesti vahekeele korpus. - Keel ja Kirjandus, nr 6, lk 436-451.

H a bi c ht, Külli 2006. Meie muutuv kirjakeel. - Oma Keel, nr 1, lk 12-19.

Ha bi cht, Külli, Keevallik, Leelo, Tragel, Ilona 2006. Keele muutumine kasutuskontekstis. - Keel ja Kirjandus, nr 8, lk 609-625.

Ka a le p, Heiki-Jaan 2010. Mitmuse osastav eesti keele käändesüsteemis. - Keel ja Kirjandus, nr 2, lk 94-111.

$\mathrm{Ka}$ s e s a lu, Kaisa 2012. Vormiharmoonia mitmuse vormide moodustamisel. Bakalaureusetöö. Tartu Ülikooli eesti ja üldkeeleteaduse instituut.

K u k k, Inga 2010. Kõnekeelsus õpilaskirjandites. Magistritöö. Tartu Ülikooli eesti ja üldkeeleteaduse instituut.

Lang a cker, Roland W. 1987. Foundations of Cognitive Grammar, Vol. 1: Theoretical Prerequisites. Stanford: Stanford University Press.

Lang a cker, Roland W. 1988. A usage-based model. - Topics in Cognitive Linguistics. (Current Issues in Linguistic Theory 50.) Toim Brygida Rudzka-Ostyn. Amsterdam: Benjamins, lk 127-161.

Langacker, Roland W. 2000. Introduction: A usage-based conception of language. - Usage-Based Models of Language. Toim M. Barlow, S. Kemmer. Stanford-California: CSLI Publications, lk 1-63.

Metslang, Ann 2012. Varieeruva vormistikuga muuttüüpide osastava käände kasutus eesti kirjakeeles. Magistritöö. Tartu Ülikooli eesti ja üldkeeleteaduse instituut.

Mets lang, Ann 2013. Osastava käände vormide kasutamisest eesti kirjakeeles. - Keel ja Kirjandus, nr 7, lk 507-520. 
Penjam, Pille 2008. Eesti kirjakeele $m a$ - ja $d a$-infinitiiviga konstruktsioonid. (Dissertationes philologiae estonicae Universitatis Tartuensis 23.) Tartu: Tartu Ülikooli Kirjastus.

Rätse p, Huno 1979. Eesti keele ajalooline morfoloogia II. Tartu: Tartu Riiklik Ülikool.

Sahkai, Heete 2011. Teine grammatika. Eesti keele teonimede süntaks konstruktsioonipõhises perspektiivis. (Tallinna Ülikool. Humanitaarteaduste dissertatsioonid 25.) Tallinn: Tallinna Ülikooli Kirjastus.

Soodla, Karin 2010. Morfoloogilisi, morfosüntaktilisi ja sõnamoodustuslikke nähtusi eesti internetikeeles. Magistritöö. Tartu Ülikooli eesti ja üldkeeleteaduse instituut.

Tomasello, Michael 2003. Constructing a Language: A usage-based theory of language acquisition. Cambridge (Mass.)-London: Harvard University Press.

Trummer, Ireen 2005. Mitmuse osastava käände vormide kasutus eesti kirjakeeles. Bakalaureusetöö. Tartu Ülikooli eesti ja üldkeeleteaduse instituut.

Valmet, Aino 1956. Pluurali partitiiv eesti vanemas kirjakeeles (1542-1857). Kandidaadiväitekiri. Tartu Ülikooli eesti ja üldkeeleteaduse instituut.

\section{Variation in the partitive plural sid- and si-endings: A usage-based analy- sis}

Keywords: morphology, variation, partitive, Internet language, noun, Estonian

This study investigates the choice between the partitive plural case sid-and siendings as manifested in Internet Estonian. The sid-ending is grammatically correct in Standard Estonian, whereas the $s i$-ending is not. However, the si-ending is known to occur in student essays as well as in online communications. The research question examined in this study was which words exhibit more variation in terms of the sid-and si-endings. The words were considered from the aspects of inflectional type, part of speech, phrase analogy, and position in the turn.

The material analysed comes from new media texts available in the text corpora of the University of Tartu. The preference for the sid-or si-ending is explained from the usage-based theory.

The results of the study indicate that sid-and si-endings tend to vary more if the words belong to the auto or ema inflection types. In part-of-speech terms, nouns vary more than adjectives. But it should be kept in mind that the analysed material included more nouns than adjectives. As for phrase analogy, the head depends on the modifier more frequently than the modifier depends on the head. According to the position in the turn, the sid-ending forms are more likely to occur at the end of the turn, while the si-ending forms rather belong to the beginning of the turn. The most frequent words preferring the si-ending over the sid-ending were image 'image', kalla 'darling sl.', mersu 'Mercedes-Benz car', musi 'sweety, lit. kiss', muuvi 'movie sl.', naiska 'woman sl.', noku 'penis sl.', norm 'normal sl.', pube 'teenager sl.', semu 'buddy', soovilugu 'request song', soprano 'The Sopranos series', spoila 'spoiler', sudoku 'sudoku', and vibu 'bow'.

Ann Metslang (b. 1988), MA, doctoral student of Estonian and Finno-Ugric Linguistics at the University of Tartu, ann.metslang@ut.ee 